\title{
Armin Eich, Stefan Freund, Meike Rühle, Christoph Schubert (eds.), Das dritte Jahrhundert. Kontinuitäten, Brüche, Übergänge. Ergebnisse der Tagung der Mommsen-Gesellschaft am 21.-22.11.2014 an der Bergischen Universität Wuppertal (Palingenesia - 108), Franz Steiner Verlag 2017, 286 pp., b/w ill., ISBN 978-3-515-11841-5
}

For historians of Rome, the third century CE is mostly associated with the major crisis that beset the Roman state. The sources of this portrayal of the century were the political chaos of the time (manifested by the high number of short-term rulers on the throne) as well as Rome's weakened military capabilities, which left the emperors unable to effectively protect its borders. Scholars' interest in evaluating and analysing the events of the third century remains unflagging. It is not only the political and military events that are the subject of this focus, however. They also pay attention to other areas of life, which, despite the numerous instances of unrest, continued as usual, as well as undergoing profound transformations related to the new phenomena in social and religious life, culture and art. The resultant changes were the subject of the conference "Das 3. Jahrhundert nach Christus - Kontinutitäten im Übergang," which took place at the University of Wuppertal in 2014. A selection of the papers presented at this interdisciplinary conference has now been published. The participation of representatives of various academic disciplines was intended to engender discussion of various types of processes and phenomena from the third century $\mathrm{CE}$ without linking them to the general crisis of the century. The originality of this perspective of this period in Roman history is made clear by both the second part of the conference title and the subtitle of the book.

The logic behind the book's order is not immediately made clear by its contents page. It is not arranged either in alphabetical order by author name, or by any clear division by content. The titles of the specific articles alone give an indication that their subject matter is history, legal history, history of philosophy and Christian literature. Yet this division should only be treated as a rough one. The largest group of texts are those which address, in whole or in part, early Christian literature and art (K. Degen, "Haec non minora veteribus exempla. Die Darstellung der Märtyrer als exempla nova in den frühchristlichen Martyriumsberichten," pp. 97-110; E. Heck, "Der Antiklassizistische Anfang christlicher Dichtung lateinischer Sprache: Commodian,” pp. 111-122; S. Moraw, “Odysseus in der Sepulkralkunst der Stadt Rom. Eine Allegorie für die menschliche Seele?,” pp. 123-146; O. Ehlen, "Kontinuität und Diskontinuität und der sogenannte ,christliche Roman'. Von der eigentümlichen Verwendung paganer Romanmotivik in der griechischen Fassung des Martyrium Petri," pp. 147-153; H. G. Nesselrath, "Eine religiös-philoso- 
phische Leitfigur: zwischen Vergangenheit und Zukunft: Philostratos Apollonios,” pp. 155-169; C. Scardino, "Iulius Africanus. Ein römischer Höfling und christlicher Sophist im Zeitalter der Severer," pp. 171-187).

These texts show that Christian authors successfully made use of many elements borrowed from the traditions of Greek and Roman literature, and even art. By adapting these aspects, or sometimes even giving them a new meaning, they were able to meet the intellectual and religious needs of their Christian readers. Particularly interesting in this respect is Moraw's article, which describes how the figure of Odysseus was used in Christian art.

Two papers concern legal and socio-legal history. In his article "Warum endete gegen Mitte des 3. Jahrhunderts die klassische Rechtliteratur?” (pp. 57-73), D. Liebs attributes the decreased development of Roman legal history from the mid-third century onwards to the emperors' increasing amounts of personal authority, which determined the interpretation of the law. This is particularly visible among those emperors who placed the army on the throne. The circumstances of their acquisition of power made the interpretations of trained lawyers superfluous. E. Köstner ("Ein göttlich-kaiserliches Geschenk mit Nachteilen? Die veränderte Situation der Neu-Römerinnen nach der Constitutio Antoniniana," pp. 203-220) points to certain aspects of the legal situation of women following the implementation of Constitutio Antoniniana. She argues that the resolutions of this document by no means entailed an automatic improvement in the situation of all women. Certain groups even lost some of the privileges they had previously gained, since the new regulations meant that their legal independence was curtailed. This did not occur immediately, however, but rather through the evolutionary process of unification of the legal system during the third century CE.

Interesting reflections on the economic problems of the era are provided by W. Jongman's article "Das römische Wirtschaftswunder und sein Zusammenbruch" (pp. 35-55). Scholars have often noted a connection between the breakdown of the political and military structures of the Roman state in the third century CE and its worsening economic situation. According to Jongman, there are no grounds for this argument. At least some of the economic problems which the state experienced were a consequence of phenomena and events that had taken place in the second century. These included the Antonine Plague from the time of Marcus Aurelius, but also climate changes, resulting in worsening conditions for agriculture. Changes to Rome's political system also played a significant role in deepening the economic problems. As the emperor's personal powers continued to expand, methods of rule became increasingly authoritarian and repressive, and high tributes were exacted upon subjects.

L. Grozdanova's contribution ("Niedermöesien und Thrakien unter der Herrschaft des Philippus Arabs und seines Sohnes Philipp II (244-249 n. Chr.)," pp. 251-266) is the only one in the book to examine the political history of the third century CE. Based on an analysis of the minting of the cities of Moesia Inferior and Thracia as well as epigraphical evidence, the author attempts to show that Philip the Arab was present in Thracia in $244 \mathrm{CE}$, and his son Philip II on the coast of Moesia around $247 \mathrm{CE}$. The importance of Grozdanova's conclusions is that they throw light on the activity of this emperor, as well as the situation in these two provinces on the Danube. J. Grusková and G. Martin's article ("Rückkehr zu den Thermopylen. Die Fortsetzung einer Erfolgsgeschichte in den neuen 
Fragmenten Dexippos von Athen," pp. 267-281) occupies a place somewhere between history and philology. It refers to an episode mentioned in a recently discovered passage from a historical work by Dexippus, which mentions the struggle with the barbarians endangering Greece. The precise date of these events is hard to pinpoint. What the authors are more interested in, however, is the question of the enduring historical memory of the Greeks - the Roman dignitary Marianus alluded to in the text calls upon them to resist at Thermopylae, reminding them that their ancestors had done so several times in the past - as well as Dexippus' use of rhetoric. Questions of rhetoric and philosophical matters are also the subject of the papers by N. Hömke ("Mit Gift und Dirnen römische Werte bewahren? Die pseudoquintilianischen Declamationes maiores 14 und 15 zwischen Kontinuität und Wandel," pp. 203-220), C. Tornau ("Spuren philosophischen Debatten im 3. Jahrhundert?," pp. 221-238) and P. Weitman ("Pindar, Plotin, die Schönheit und das Licht," pp. 239-250). Two more articles need to be mentioned. First, S. Diederich ("Römisches Bildungswissen im 3. Jahrhundert - Bruch oder Kontinuität?," pp. 75-95) reconstructs the typical contents of the educational programme of young Romans in the third century. Second, W. Raeck ("Das dritte nachchristliches Jahrhundert in der archäologischen Forschung und Bewertung. Das Beispiel des Porträts," pp. 15-33) provides an overview of the history of research on the Roman portrait and the assessments of it made from the 1920s, when such studies commenced, to the present day.

The tremendous variety of issues and subjects presented in the various papers in this book make it clear that it is impossible to evaluate the third century CE solely from the perspective of the political and military events that took place. Scholars have sufficient historical evidence available to examine this century from various points of view, and the conclusions resulting from their analyses by no means prove that the crisis of the Roman state was reflected in all areas of life. In many of them we can observe the continuation of phenomena that appeared considerably earlier. In others we see the emergence of changes resulting from aspirations to adapt already known traditions and norms to the needs of the era. This is not to say that the previous models were not sometimes discarded. Reading this book, we can conclude that such changes mostly took place in the areas of life with close links to the political sphere. 